\title{
Association of Career Satisfaction with Stress and Depression: The Case of Preservice Music Teachers
}

\author{
Sabahat Burak ${ }^{1} \&$ Oguzhan Atabek ${ }^{1}$ \\ ${ }^{1}$ Faculty of Education, Akdeniz University, Antalya, Turkey \\ Correspondence: Sabahat Burak, Faculty of Education, Akdeniz University, Antalya, 07058, Turkey. E-mail: \\ buraksabahat@gmail.com
}

Received: July 16, 2019

Accepted: August 10, 2019 Online Published: September 20, 2019

doi:10.5539/jel.v8n5p125

URL: https://doi.org/10.5539/jel.v8n5p125

\begin{abstract}
In order to investigate the relationships between preservice music teachers' levels of career satisfaction, severity of depression, and perceived stress, ninety-four students enrolled in the music education BSc program of the faculty of education at a public university in southwestern part of Turkey were survey. Data were collected by Beck's Depression Inventory, Perceived Stress Scale, and Career Satisfaction Scale. Associations were analyzed by ANOVA, Pearson's product-moment correlation coefficient, and multiple linear regression. It was found that preservice music teachers' stress and depression levels were significantly higher compared to previously reported means while career satisfaction levels were lower. Preservice music teachers' career satisfaction scores significantly differed according to the grade level. There was a strong positive relationship between severity of depression and perceived stress level while career satisfaction was weakly and negatively associated with both severity of depression and perceived stress. Finally, career satisfaction neither was a predictor of nor predicted by stress or depression.
\end{abstract}

Keywords: teacher training, career satisfaction, perceived stress, depression, music education

\section{Introduction}

Qualified teachers are essential for effective music instruction. However, teacher qualifications alone may not be sufficient for achieving success in music education. Dinham and Scott (1996) argue that satisfaction, health, and motivation of teachers, who are charged with the task of educating youth and meeting society's educational demands, is a key issue. On the other hand, societal or extrinsic factors are continuously making teaching a less attractive career for both practicing and prospective teachers (Dinham \& Scott, 2000). Since dissatisfaction is associated with beginning teacher attrition, teacher burnout, teacher dropout, teachers' health problems, and decreased productivity, teacher satisfaction has increased in importance (Castle \& Martin, 2006; Inci \& Burak, 2017; Ingersoll \& Smith, 2003; Payne, Blackwell, \& Collins, 2010; Tschannen-Moran, Hoy, \& Hoy, 1998; Zembylas \& Papanastasiou, 2004). Therefore, insight into satisfaction of teachers is needed for solutions to the problems currently facing practicing and prospective teachers as well as education in general (Dinham \& Scott, 2000), especially in developing countries (Zembylas \& Papanastasiou, 2004) like Turkey.

In addition to a number of different factors, pursuit of satisfaction is significantly tied to the consequences of satisfaction or dissatisfaction with career (Judge, Scott, \& Ilies, 2006; Payne et al., 2010). Identifying factors that affect teachers' career satisfaction may contribute to the development of evaluation systems to provide teachers with a more positive sense of their career experience and progress (Conley, Muncey, \& You, 2005). On the other hand, Payne et al. (2010) report that quality of the education that workers received is related to the career satisfaction of those workers. Hence, research into career satisfaction of teachers may contribute to the improvement of the education provided by teacher training institutions. Moreover, mental distress is reported to be a predictor of career satisfaction (Dinham \& Scott, 1996). Career satisfaction is also tied to stress, depression, health problems, and burnout (Becker, Millard, \& Klock, 2006; Castle \& Martin, 2006; Ferguson, Frost, \& Hall, 2012; Payne et al., 2010). Stress and depression experienced by the teachers affect their teaching (Montgomery, \& Rupp, 2005; Shin, Noh, Jang, Park, \& Lee, 2013). Depression is one of the primary psychological or emotional disturbances that stressed individuals do experience (Tsai, Fung, \& Chow, 2006). Teaching is argued to be one of the most stressful occupations in many countries (Cooper, Sloan, \& Williams, 1988) and career satisfaction of teachers has been an issue of concern for many years (Akiri, 2014). Therefore, this study aims to 
investigate the association of career satisfaction with depression and perceived stress levels of preservice music teachers.

\subsection{Career Satisfaction}

Career satisfaction is defined as "an individual's awareness of his/her current career achievements and projections for future advancement" (Kang, Gatling, \& Kim, 2015, p. 72) or "an individual's satisfaction with his or her career accomplishments" (p. 70). In another point of view; career satisfaction is "the satisfaction individuals derive from intrinsic and extrinsic aspects of their careers, including pay, advancement, and developmental opportunities" (Judge, Cable, Boudreau, \& Bretz, 1995, p. 487). Career satisfaction is a well-studied concept especially regarding its effects on individual and on job performance (Lepnurm, Dobson, Backman, \& Keegan, 2007). It is associated with salary, relationships with colleagues in the department, departmental climate (August \& Waltman, 2004); role ambiguity and work criteria autonomy (Conley et al., 2005). Additionally, it is reported that supervisory support has a positive effect on career satisfaction (Kang et al., 2015). Kumudha and Abraham (2008) stated that primary support programs related to self-development, information about job openings, and opportunities to learn new skills have contributed to the feeling of career satisfaction. Moreover; student achievement, helping students to modify their attitudes and behavior, positive relationships with students and others, self-growth, mastery of professional skills, and feeling part of a collegial, supportive environment are reported to be powerful predictors of career satisfaction (Dinham \& Scott, 1996; Dinham \& Scott, 2000).

Career satisfaction is also a determinant of job performance and career commitment. Career commitment is defined as "attitude towards one's profession or vocation" (Blau, 1985, p. 278). Fu (2010) stated that career satisfaction was the most important determinant of career commitment. Job performance is defined as "a worker's effective execution of tasks or job and useful contribution to the social work environment" (Abramis, 1994, p. 549). Riaz and Haider (2010) found high correlation between job success and career satisfaction. Leadership (Wong \& Laschinger, 2013) and social efficacy beliefs (Hochwarter, Kiewitz, Gundlach, \& Stoner, 2004) were found to be the predictors of both job performance and career satisfaction. Career satisfaction is also related with psychological conditions such as stress, depression, and burnout. Becker et al. (2006) found that career satisfaction was inversely correlated with burnout and depression. Similarly, Ferguson et al. (2012) reported that teachers' stress and depression had a significant and negative impact on job satisfaction. Teacher's emotional states - particularly depression and stress - are also related to his or her performance in the classroom (Ripski, LoCasale-Crouch, \& Decker, 2011). On the other hand, since career satisfaction is associated with being able to cope with stress (Lepnurm et al., 2007) shedding light on the dynamics of career satisfaction and emotional states such as stress and depression may contribute to the design, development and providing of strategies and resources for practicing and prospective teachers to confront the challenges of becoming and being a teacher.

\subsection{Stress}

Stress has different meanings "for different people under different conditions" (Fink, 2009, p. 5). The most generic definition of stress is proposed by Hans Selye: "[s]tress is the nonspecific response of the body to any demand" (Selye, 1976, p.74). It is also defined as "a real or interpreted threat to the psychological or psychological integrity of an individual that results in psychological or/and behavioral responses" (McEwen, 2010, p.11). Stress also has sub-concepts such as teacher stress or teaching stress. Borg and Riding (1991) defined teacher stress as "a condition of negative affects (e.g., anger) resulting from aspects of the teacher's job which are perceived by the teacher as a threat to his/her psychological or physical well-being" (p. 266). Teacher stress is also defined as "the experience by a teacher of unpleasant, negative emotions, such as anger, anxiety, tension, frustration or depression, resulting from some aspect of their work as a teacher" (Kyriacou, 2001, p. 38). Teaching related stress can affect a teacher's health, well-being, and performance (Larchick \& Chance, 2004). Similar with other forms of occupational stress, in addition to the personal health of the teacher, teacher stress can have serious implications for the organization in which the individual serves (Tsai et al., 2006).

Music has a role in alleviating or reducing the physiological effects of stress (Khalfa, Roy, Peretz \& Lupien, 2003; Knight \& Rickard, 2001). However, this role does not preclude preservice and inservice music teachers from experiencing stress. Hodge, Jupp, and Taylor (1994) found that music teachers were substantially more distressed and burnt out compared to mathematics teachers. Sources of stress for music teachers are varied (Dewe, 1986; Tsai et al., 2006). For example, Brown (1987) reported that, music teachers find the job-related stressors as the most stressful ones. Gordon (2002) found that management is a prevalent stressor for music educators. In the same study, music educators suggested that students' apathy, behaviors, attitudes, and lack of 
motivation to learn were pervasive stressors. In another study, Gordon $(2000, \mathrm{p}, 27)$ reported the sources of stress as: (1) behaviors and attitudes of students, colleagues, parents, and administrators; (2) difficulties of program management which negatively affect the music curriculum and offerings; and (3) inadequate preservice preparation for music. Burden of tedious administrative responsibilities, the constant need for music education advocacy, conflicts between personal and professional roles, and tension created by scheduling conflicts due to the increasingly busy schedules of students were also reported to be among the most significant stressors for music teachers (Scheib, 2003).

Music teachers and teachers of other branches vary in the sources of stress. Some of the sources of stress occur due to the nature of music itself, as well. Sternbach (2008) states that music students are exposed to the stresses of their age together with their peers and they have to cope with stress sources that are unique to music. For example, music students spend more time on music activities such as concerts and rehearsals than their peers, which may cause them not to spend enough time for relaxation and entertainment. Going on stage and preparing for it is another source of stress. Another source of stress is that the focus required by playing the instrument causes introversion and thus decreases social interaction. Both self-criticism and the criticisms coming from the environment regarding the performance of music by music teachers are also sources of stress unique to music (Sternbach, 2008).

\subsection{Depression}

Depression, which is also called clinical depression or major depressive disorder, is defined by American Psychiatric Association as "a common and serious medical illness that negatively affects how you feel, the way you think and how you act" (Parekh, 2017). National Institute of Mental Health of the United States of America (2018) states that depression is a common but serious mood disorder. The institute indicates that depression causes severe symptoms that affect how individuals feel, think, work, and handle daily activities. In an operational sense, depression is also defined as the medical illness experienced by individuals who meet necessary criteria as measured by the Beck Depression Inventory (Beck, Ward, Mendelson, Mock, \& Erbaugh, 1961; Carroll \& Robinson, 2000). Çoban (2005) states that depression is a psychiatric condition in which a person feels depressed, sad, and has complaints such as slowing speech and movements, stagnation, thoughts of worthlessness, susceptibility, loss of confidence, reluctance, and inability to work. Siegrist (2008) suggests that, due to their high prevalence and severe consequences, depressive disorders provide a primary challenge to medicine and public health.

In addition to stress, teachers' performance in the classroom is linked to depression (Hamre \& Pianta, 2004; Ripski, LoCasale-Crouch, \& Decker, 2011; Uzman \& Telef, 2015). Teacher candidates with higher levels of depression and stress implement a less qualified teaching in the following years when they interact with students (Ripski, LoCasale-Crouch, \& Decker, 2011). Depression and stress are the most common psychiatric health problems teachers experience (Uzman \& Telef, 2015). Hildebrandt, Nübling, and Candia (2012) claimed that in recent times, a clear association between psychosocial stress in work environments and risk for depression has been presented. Shin et al. (2013) found a significant relationship between teacher burnout and depression. Hammen and DeMayo (1982) reported that teachers experience a high degree of stress-related depressive symptomatology.

Previous research shows that music has positive effects on reducing depression (Field, Martinez, Nawrocki, Pickens, Fox, \& Schanberg, 1998; Magee \& Davidson, 2002; Siedliecki \& Good, 2006; Waldon, 2001). However, dealing with music is not enough to avoid depression. Spahn, Strukely, and Lehmann (2004) reported that music students rated $8.4 \%$ in depression scale and $33.5 \%$ on the anxiety scale, which was significantly more than the other students were and placed them in the borderline or elevated range. Moreover, Wristen (2013) found that, among music students at university, a considerable number of students show symptoms indicative of anxiety or depression. She also took attention to the high rate of untreated anxiety and depression among the music students (Wristen, 2013).

\section{Method}

The study was designed as a correlational research. Throughout the study, Ethical Principles of Psychologists and Code of Conduct have been observed (American Psychological Association, 2002). Only consenting individuals have participated in the research.

\subsection{Participants}

Ninety-four preservice music teachers participated in the study. All the participants were students enrolled in the music education BSc program of the faculty of education at a public university in southwestern part of Turkey 
$(\mathrm{N}=94)$. Of 94 preservice music teachers; $51(54.3 \%)$ were female $(0)$ and $43(45.7 \%)$ were male $(1)(\overline{\mathrm{x}}=0.46$; $\mathrm{s}=0.501)$. Ages of the participants ranged from 18 to $34(\overline{\mathrm{x}}=21.18 ; \mathrm{s}=2.871)$. Of all participants; $28(29.8 \%)$ were first, $30(31.9 \%)$ were second, $13(13.8 \%)$ were third, and $23(24.5 \%)$ were fourth grade students $(\overline{\mathrm{x}}=2.33$; $\mathrm{s}=1.149$ ).

\subsection{Data Collection Tools}

Data were collected by a paper-and-pencil instrument comprised of Beck's Depression Inventory, Perceived Stress Scale, Career Satisfaction Scale, and a demographics form for determining participants' grade and sex.

\subsubsection{Beck's Depression Inventory}

The inventory was developed by Beck, Ward, Mendelson, Mock, and Erbaugh (1961) for measuring the severity of depression and was adapted for Turkish by Hisli (1988). The scale consists of 21 items. Score range is 0 to 63 and higher scores indicate more severe depressive symptoms. Questions are answered by one of the 4 forced choices. Every choice of the rating scale is unique. For the first question, the rating scale is as follows: $0=\mathrm{I}$ do not feel sad, 1 = I feel sad, 2 = I am sad all the time and I can't snap out of it, and $3=$ I am so sad or unhappy that I can't stand it. For the standard cut-off scores; 0-9 represents minimal depression, 10-18 represents mild depression, 19-29 represents moderate depression, and 30-63 represents severe depression. Cronbach's alpha of the scale is 0.86 .

\subsubsection{Perceived Stress Scale}

The scale was developed by Cohen, Kamarck, and Mermelstein (1983) to measure the degree to which situations in one's life are appraised as stressful. It was adapted for Turkish by Yerlikaya and İnanç (2007). The Turkish version of the scale is a 5-point Likert type scale consisting of 10 items. Score range is 0 to 40 and higher scores indicate more perceived stress. The rating scale is as follows: $0=$ Never, $1=$ Almost never, $2=$ Sometimes, $3=$ Fairly often, and $4=$ Very often. A sample item of the scale is: "In the last month, how often have you been upset because of something that happened unexpectedly?" In this research, Cronbach's alpha of the scale is 0.84 .

\subsubsection{Career Satisfaction Scale}

The scale was developed by Parayitam, Desai, Desai, and Eason (2010) and consists of three items; two items originally developed by Childs and Klimoski (1986) and one developed by Martins, Eddleston, and Veiga (2002). The scale is a 5 -point Likert type scale. The rating scale ranged from 1 (strongly disagree) to 5 (strongly agree). A sample item of the scale is: "I am satisfied with my career status". Cronbach's alpha of the scale is 0.80 .

\subsection{Procedure}

After conducting a literature review and determining the scales, the survey instrument was prepared as a paper-and-pencil survey. Permissions were received from instructors of the courses that the students take. Data were collected in the classrooms during the lessons.

\subsection{Data Analysis}

After preliminary screening of the completed survey instruments, answers of the participants were transferred to computer. Data were stored, arranged, reviewed, and analyzed by the use of IBM SPSS Statistics computer program (IBM SPSS Statistics Version 25). In addition to descriptive techniques, the data were analyzed by Cronbach's $\alpha$ estimate, t-test, one-way analysis of variance (ANOVA), Tukey's HSD, Pearson's product-moment correlation coefficient, and multiple linear regression. Cronbach's $\alpha$ internal consistency estimate was calculated for the scales in order to check the reliability of the instrument. While t-test was conducted for gender differences, ANOVA and Post-Hoc Tukey's HSD test was employed for differences among grades. Pearson's product-moment correlation coefficient was computed for the correlations among Beck's depression, perceived stress, and career satisfaction levels. Finally, a multiple linear regression analysis was conducted.

\section{Results}

Initially, after calculating scale scores through both averaging and summation, a descriptive analysis was conducted on those scale scores. Table 1 depicts the results of descriptive analysis on the scales. After descriptive analyses, an independent samples t-test was performed in order to compare the levels of perceived stress, depression, and career satisfaction in females and males. Results revealed that there were no significant differences in the levels of perceived stress $(p=0.985)$, depression $(p=0.251)$, or career satisfaction $(p=0.312)$ for females and males. 
Table 1. Descriptive results for scale scores

\begin{tabular}{llllllllll}
\hline & & \multicolumn{9}{c}{ Mean of Scores } & \multicolumn{7}{c}{ Sum of Scores } \\
\cline { 2 - 11 } & Min. & Max. & $\overline{\mathrm{x}}$ & $\mathrm{s}$ & Min. & Max. & $\overline{\mathrm{x}}$ & $\mathrm{s}$ \\
\hline Perceived Stress & 94 & 0.40 & 3.70 & 2.27 & 0.68 & 4 & 37 & 22.66 & 4.51 \\
Depression & 93 & 0.10 & 2.24 & 0.72 & 0.43 & 2 & 47 & 14.78 & 9.05 \\
Career Satisfaction & 94 & 1.00 & 5.00 & 3.76 & 0.92 & 3 & 15 & 11.29 & 2.78 \\
\hline
\end{tabular}

In the next step, three sets of ANOVA were conducted on the levels of perceived stress, depression, and career satisfaction to determine if the scores vary according to grades of preservice music teachers. Table 2 illustrates the results of the ANOVA computations. First ANOVA showed that there was not a significant effect of grade on perceived stress, $F(3,90)=1.870, p=0.140$. Similarly, there was not a significant effect of grade on depression as determined by second ANOVA, $\mathrm{F}(3,89)=1.030, \mathrm{p}=0.383$. In contrast, third ANOVA computation revealed that there was a significant difference in career satisfaction levels between grades, $F(3,90)=4.226, p=0.008, \eta^{2}$ $=0.12$. A Tukey HSD post hoc test revealed that mean career satisfaction score of $4^{\text {th }}$ graders $(\overline{\mathrm{x}}=3.20, \mathrm{~s}=0.90)$ is significantly lower than the scores of $1^{\text {st }}(\overline{\mathrm{x}}=4.02, \mathrm{~s}=0.90, \mathrm{p}=0.007)$ and $2^{\text {nd }}(\overline{\mathrm{x}}=3.91, \mathrm{~s}=0.76, \mathrm{p}=0.024)$ graders.

Table 2. Results of ANOVA using grade as the criterion

\begin{tabular}{llllllll}
\hline & & SS & MS & df & F & p & $\eta^{2}$ \\
\hline Perceived Stress & Btw. Groups & 2.527 & 0.842 & 3 & 1.870 & 0.140 & \\
& Wth. Groups & 40.544 & 0.450 & 90 & & & \\
& Total & 43.071 & & 93 & & & \\
Depression & Btw. Groups & 0.574 & 0.191 & 3 & 1.030 & 0.383 \\
& Wth. Groups & 16.524 & 0.186 & 89 & & & \\
Career Satisfaction & Total & 17.097 & & 92 & & & \\
& Btw. Groups & 9.868 & 3.289 & 3 & $4.226^{*}$ & 0.008 & \\
& Wth. Groups & 70.048 & 0.778 & 90 & & & \\
\hline
\end{tabular}

Note. "*"p $<0.05$. "Btw." and "Wth." stand for between and within, respectively.

After the t-test and ANOVA, Pearson's product-moment correlation coefficients were computed for the relationships between perceived stress, depression, and career satisfaction in order to measure the strength and direction of possible associations. Results of the computations are displayed in Table 3. There was a weak, negative correlation between career satisfaction and perceived stress, which was statistically significant $(\mathrm{r}=$ $-0.297, \mathrm{n}=94, \mathrm{p}=0.004)$. Similarly, there was a weak, negative correlation between career satisfaction and depression, which was again statistically significant $(r=-0.291, n=93, p=0.005)$. On the other hand, there was a strong, positive correlation between perceived stress and depression, which was statistically significant $(\mathrm{r}=$ $0.671, \mathrm{n}=93, \mathrm{p}=0.000$ ).

Table 3. Results of Pearson's correlation coefficient computations

\begin{tabular}{lllll}
\hline & & Career Satisfaction & Perceived Stress & Depression \\
\hline Career Satisfaction & Pearson Correlation & 1 & $-0.297^{*}$ & $-0.291^{*}$ \\
& Significance (2-tailed) & & 0.004 & 0.005 \\
& N & 94 & 94 & 93 \\
Perceived Stress & Pearson Correlation & $-0.297^{*}$ & 1 & $0.671^{* *}$ \\
& Significance (2-tailed) & 0.004 & & 0.000 \\
Depression & N & 94 & 94 & 93 \\
& Pearson Correlation & $-0.291^{*}$ & $0.671^{* *}$ & 1 \\
& Significance (2-tailed) & 0.005 & 0.000 & 93 \\
\hline
\end{tabular}

Note. “*”p $<0.01$ and “**” $<<0.001$. "N" stands for sample size.

Finally, three multiple linear regression analyses were conducted. The first regression model was used to test if depression and career satisfaction significantly predicted perceived stress. Results of the analysis indicated that 
$46.2 \%$ of the variance in perceived stress was explained by only one of the predictors $\left(\mathrm{R}^{2}=0.462, \mathrm{~F}(2,90)=\right.$ $38.685, p=0.000)$. It was found that depression significantly predicted perceived stress $(\beta=0.638, p=0.000)$. The second regression model was used to test if perceived stress and career satisfaction significantly predicted depression. Results of the analysis indicated that $46 \%$ of the variance in depression was explained by again one of the predictors $\left(\mathrm{R}^{2}=0.459, \mathrm{~F}(2,90)=38.247, \mathrm{p}=0.000\right)$. It was found that perceived stress significantly predicted depression $(\beta=0.642, p=0.000)$. Career satisfaction was not a significant predictor in both models. The third regression model was used to test if perceived stress and depression significantly predicted career satisfaction. Even though the model was significant $\left(R^{2}=0.104, F(2,90)=5.233, p=0.007\right)$, it was found that neither perceived stress $(\beta=-0.189, \mathrm{p}=0.164)$ nor depression $(\beta=-0.164, \mathrm{p}=0.226)$ could significantly predict career satisfaction.

\section{Discussion}

The purpose of the study was to investigate the relationships between career satisfaction, depression, and perceived stress levels of preservice music teachers. Initially, it was found that preservice music teachers' levels of perceived stress and severity of depression were significantly high while career satisfaction levels were low. Mean career satisfaction level of preservice music teachers (3.76) was considerably lower compared to previously reported mean with a sample of undergraduate and graduate students (Parayitam et al., 2010). In contrast, mean perceived stress level (22.66) was quite higher compared to previously reported norms (14.2) with a general population sample of 18 to 29 years of age (Cohen, 1994). Similarly, mean level of severity of depression (14.78) was higher than the norm mean value (9.14) reported by Whisman and Richardson (2015). Additionally, the proportion of preservice music teachers who scored 19 and above on Beck's Depression Inventory and therefore associated with moderate to severe depressive symptoms was $26.6 \%$, which in turn was considerably higher than the proportion of undergraduate students $(12 \%)$ as reported by Whisman and Richardson (2015). Moreover, mean values do not differ according to gender. On the other hand, high levels of stress and depression among preservice music teachers is in parallel with previous research on professional musicians (Breda \& Kulesa, 1999; Smith, Brice, Collins, Matthews, \& McNamara, 2000; Steptoe, 1989; Vaag, Bjørngaard, \& Bjerkeset, 2016).

Results of ANOVA on the effect of grade of preservice teachers indicate that levels of perceived stress and severity of depression do not differ according to the grade level of the students. However, career satisfaction scores significantly differ according to the grade level; mean levels significantly dropping from 4.02 to 3.91 between $1^{\text {st }}$ and $2^{\text {nd }}$ grades and from 3.91 to 3.20 between $2^{\text {nd }}$ and $4^{\text {th }}$ grades. Remarkably, results indicate that aspiring music teachers come to teacher training institutions with considerably higher stress and depression levels, even though being satisfied with their career progress to-date. From $1^{\text {st }}$ to $4^{\text {th }}$ grade, stress and depression levels stand firm in the aforementioned higher position while career satisfaction levels decline. Results indicate that preservice music teachers are as worried about their "career development" as professional musicians (Cooper \& Wills, 1989; Wills \& Cooper, 1987) and they are more concerned as they learn more about their profession. Interestingly, music seems to be failing to fulfill the role of alleviating the effects of stress (Khalfa et al., 2003; Knight \& Rickard, 2001) and depression (Field et al., 1998; Magee \& Davidson, 2002; Siedliecki \& Good, 2006; Waldon, 2001) for preservice music teachers, in parallel with the findings of Hodge et al. (1994), Spahn et al. (2004), and Wristen (2013). Possible positive effects of music may be hindered by the sources of stress occurring due to the nature of music itself such as spending long periods of time on music activities like concerts and rehearsals, going on stage and preparing for it, self-criticism and the criticisms coming from the environment regarding the performance of music, focus required by playing the instrument, and not having enough time for relaxation and entertainment (Sternbach, 2008).

Findings from correlational analyses indicate a strong positive relationship between severity of depression and perceived stress level while career satisfaction is weakly and negatively associated with both severity of depression and perceived stress level. Previous research indicates that there are complex interactions between stress and depression (Fagundes, Glaser, Hwang, Malarkey, \& Kiecolt-Glaser, 2013). Stress is one of the causes of depression (Maddock \& Pariante, 2001; Sherina, Rampal, \& Kaneson, 2004; Welch \& Austin, 2001) while being depressed is a predictor of perceived stress (Olinger, Kuiper, \& Shaw, 1987). Hence, strong correlation between perceived stress and severity of depression is in parallel with previous research that stress is both an etiology and a symptom of depression. Regression models also indicate that perceived stress and severity of depression predict approximately $46 \%$ of variance in each other. However, career satisfaction neither is a predictor of nor predicted by stress or depression.

Even though there is a relationship between three of the variables, findings of this study indicate that - since stress and depression doesn't but career satisfaction do vary according to grade levels - career satisfaction is 
controlled by factors other than perceived stress and severity of depression while also correlating with them. The decline in career satisfaction may be due to the facts that preservice teachers have learned about their future profession during their university education such as teacher salary (August \& Waltman, 2004; Judge et al., 1995), advancement and developmental opportunities (Abraham, 2008; Conley et al., 2005; Judge et al., 1995) workplace conditions and relationship with other colleagues and administrators (August \& Waltman, 2004; Conley et al., 2005; Dinham \& Scott, 1996; Dinham \& Scott, 2000; Kang et al., 2015), possibility of succeeding in the job (Wong \& Laschinger, 2013) and social efficacy beliefs (Hochwarter et al., 2004). During their field teaching practice, pre-service teachers may have had experiences which caused them to face with their teaching competences or which were not compatible with their existing mental models regarding being a teacher. Additionally, it was reported that the development of pre-service teachers' professional identity during field teaching practice has an effect on their professional commitment through emotional evaluation of and belief in the teaching profession (Zhao \& Zhang, 2017). Findings of this study revealed that, experiences of pre-service teachers during their field teaching practice might have negatively influenced their emotional evaluation of and belief in the teaching profession. Therefore, preservice music teachers may be losing faith in their career progression as they learn more about what it actually means for a young individual to be a teacher in the classroom.

Finding of this study revealed that, preservice music teachers need resources that may help them cope with stress and depression during their education. It should also be noted that depression is a serious illness and letting depressed individuals to practice teaching profession may produce more serious problems for children as well as the teacher himself. Hence, reaching out freshmen for letting them to be aware of their health status is important for being able to provide them the opportunities and resources for coping with stress and depression. On the other hand, teaching profession may be in need of serious intervention for the improvement of the working conditions. Such decline in career satisfaction levels of preservice teachers after learning more about the real-world working conditions of teaching profession needs to be taken into consideration by policy makers, administrators, education entrepreneurs, and other related parties.

\section{References}

Abramis, D. J. (1994). Relationship of job stressors to job performance: Linear or an inverted-U? Psychological Reports, 75(1), 547-558. https://doi.org/10.2466/pr0.1994.75.1.547

Akiri, A. A. (2014). Teachers' career satisfaction and students' academic performance in delta public secondary schools. Journal of Educational and Social Research, 4(1), 267-272. https://doi.org/10.5901/jesr.2014.v4n1p267

American Psychological Association. (2002). Ethical principles of psychologists and code of conduct. American Psychologist, 57(12), 1060-1073. https://doi.org/10.1037/0003-066X.57.12.1060

August, L., \& Waltman, J. (2004). Culture, climate, and contribution: Career satisfaction among female faculty. Research in Higher Education, 45(2), 177-192. https://doi.org/10.1023/B:RIHE.0000015694.14358.ed

Beck, A. T., Ward, C. H., Mendelson, M., Mock, J., \& Erbaugh, J. (1961). An inventory for measuring depression. Archives of General Psychiatry, 4(6), 561-571. https://doi.org/10.1001/archpsyc.1961.01710120031004

Becker, J. L., Milad, M. P., \& Klock, S. C. (2006). Burnout, depression, and career satisfaction: cross-sectional study of obstetrics and gynecology residents. American Journal of Obstetrics and Gynecology, 195(5), 1444-1449. https://doi.org/10.1016/j.ajog.2006.06.075

Blau, G. J. (1985). The measurement and prediction of career commitment. Journal of occupational Psychology, 58(4), 277-288. https://doi.org/10.1111/j.2044-8325.1985.tb00201.x

Borg, M. G., \& Riding, R. J. (1991). Occupational stress and satisfaction in teaching. British Educational Research Journal, 17(3), 263-281. https://doi.org/10.1080/0141192910170306

Breda, J., \& Kulesa, P. (1999). Stress and job satisfaction among symphony musicians. Evanston, Illinois, USA: Symphony Orchestra Institute.

Brown, P. A. (1987). An investigation of problems which cause stress among music teachers in Tennessee. Unpublished doctoral dissertation, University of Tennessee, Tennessee, USA. Retrieved from https://trace.tennessee.edu/utk_graddiss/4064

Carroll, J. J., \& Robinson, B. E. (2000). Depression and parentification among adults as related to parental workaholism and alcoholism. The Family Journal, 8(4), 360-367. 
https://doi.org/10.1177/1066480700084005

Castle, T. L., \& Martin, J. S. (2006). Occupational hazard: Predictors of stress among jail correctional officers. American Journal of Criminal Justice, 31(1), 65-80. https://doi.org/10.1007/BF02885685

Childs, A., \& Klimoski, R. J. (1986). Successfully predicting career success: An application of the biographical inventory. Journal of Applied Psychology, 71(1), 3. https://doi.org/10.1037/0021-9010.71.1.3

Cohen, S. (1994). Perceived stress scale. Palo Alto, CA, USA: Mind Garden. Retrieved from http://www.mindgarden.com/documents/PerceivedStressScale.pdf

Cohen, S., Kamarck, T., \& Mermelstein, R. (1983). A global measure of perceived stress. Journal of Health and Social Behavior, 24, 385-396. https://doi.org/10.2307/2136404

Conley, S., Muncey, D. E., \& You, S. (2005). Standards-based evaluation and teacher career satisfaction: A structural equation modeling analysis. Journal of Personnel Evaluation in Education, 18(1), 39-65. https://doi.org/10.1007/s11092-006-9008-1

Cooler, C. L., Sloan, S., \& Williams, S. (1988). Occupational stress indicator. Slough, UK: NFER-Nelson. https://doi.org/10.1037/t12433-000

Cooper, C. L., \& Kelly, M. (1993). Occupational stress in head teachers: A national UK study. British Journal of Educational Psychology, 63(1), 130-143. https://doi.org/10.1111/j.2044-8279.1993.tb01046.x

Cooper, C. L., \& Wills, G. I. (1989). Popular musicians under pressure. Psychology of Music, 17(1), 22-36. https://doi.org/10.1177/0305735689171003

Çoban, A. (2005). Müzikterapi: Ruh sağllğı için müzikle tedavi. İstanbul: Timaş Yayınları.

Dewe, P. J. (1986). An investigation into the causes and consequences of teacher stress. New Zealand Journal of Educational Studies, 21(2), 145-157.

Dinham, S., \& Scott, C. (1996). Teacher satisfaction, motivation and health: Phase one of the teacher 2000 project. Paper presented to the annual meeting of the American Educational Research Association, New York, NY, USA.

Dinham, S., \& Scott, C. (2000). Moving into the third, outer domain of teacher satisfaction. Journal of Educational Administration, 38(4), 379-396. https://doi.org/10.1108/09578230010373633

Fagundes, C. P., Glaser, R., Hwang, B. S., Malarkey, W. B., \& Kiecolt-Glaser, J. K. (2013). Depressive symptoms enhance stress-induced inflammatory responses. Brain, Behavior, and Iimmunity, 31, 172-176. https://doi.org/10.1016/j.bbi.2012.05.006

Ferguson, K., Frost, L., \& Hall, D. (2012). Predicting teacher anxiety, depression, and job satisfaction. Journal of Teaching and Learning, 8(1), 27-42. https://doi.org/10.22329/jtl.v8i1.2896

Field, T., Martinez, A., Nawrocki, T., Pickens, J., Fox, N. A., \& Schanberg, S. (1998). Music shifts frontal EEG in depressed adolescents. Adolescence, 33(129), 109-116.

Fink, G. (2009). Stress: Definition and history. In G. Fink (Ed.), Stress science: Neuroendocrinology (1st ed., pp. 3-9). San Diego, CA, USA: Academic Press.

$\mathrm{Fu}$, J. (2010). Is information technology career unique? Exploring differences in career commitment and its determinants among IT and non-IT employees. International Journal of Electronic Business Management, 8(4), 272-281. Retrieved from http://ir.lib.kuas.edu.tw/handle/987654321/13884

Gordon, D. (2000). Sources of stress for the public school music teacher: Four case studies. Contributions to Music Education, 27(1), 27-40. Retrieved from https://www.jstor.org/stable/24127016

Gordon, D. G. (2002). Discipline in the music classroom: One component contributing to teacher stress. Music Education Research, 4(1), 157-165. https://doi.org/10.1080/14613800220119831

Hammen, C. L., \& DeMayo, R. (1982). Cognitive correlates of teacher stress and depressive symptoms: Implications for attributional models of depression. Journal of Abnormal Psychology, 91(2), 96-101. https://doi.org/10.1037/0021-843X.91.2.96

Hamre, B. K., \& Pianta, R. C. (2004). Self-reported depression in nonfamilial caregivers: Prevalence and associations with caregiver behavior in child-care settings. Early Childhood Research Quarterly, 19(2), 297-318. https://doi.org/10.1016/j.ecresq.2004.04.006

Hildebrandt, H., Nübling, M., \& Candia, V. (2012). Increment of fatigue, depression, and stage fright during the 
first year of high-level education in music students. Medical Problems of Performing Artists, $27(1), 43$. Retrieved from https:/www.ncbi.nlm.nih.gov/pubmed/22543322

Hisli, N. (1989). Beck Depresyon Envanterinin üniversite öğrencileri için geçerliği, güvenirliği. Psikoloji Dergisi, $7(23), 3-13$.

Hochwarter, W. A., Kiewitz, C., Gundlach, M. J., \& Stoner, J. (2004). The impact of vocational and social efficacy on job performance and career satisfaction. Journal of Leadership \& Organizational Studies, 10(3), 27-40. https://doi.org/10.1177/107179190401000303

Hodge, G. M., Jupp, J. J., \& Taylor, A. J. (1994). Work stress, distress and burnout in music and mathematics teachers. British Journal of Educational Psychology, 64(1), $65-76$. https://doi.org/10.1111/j.2044-8279.1994.tb01085.x

Inci, U., \& Burak, S. (2017). Müzik öğretmenlerinin mesleki tükenmişlikleri (Antalya ili örneği). Journal of Research in Education and Learning, 6(1), 453-463. Retrieved from http://www.jret.org/FileUpload/ks281142/File/38.ulas_inci.pdf

Ingersoll, R. M., \& Smith, T. M. (2003). The wrong solution to the teacher shortage. Educational Leadership, 60(8), $\quad 30-33 . \quad$ Retrieved from http:/www.ascd.org/publications/educational-leadership/may03/vol60/num08/The-Wrong-Solution-to-the-T eacher-Shortage.aspx

Judge, T. A., Cable, D. M., Boudreau, J. W., \& Bretz, R. D. (1995). An empirical investigation of the predictors of executive career success. Personnel Psychology, 48(3), $485-519$. https://doi.org/10.1111/j.1744-6570.1995.tb01767.x

Judge, T. A., Scott, B. A., \& Ilies, R. (2006). Hostility, job attitudes, and workplace deviance: Test of a multilevel model. Journal of Applied Psychology, 91(1), 126-138. https://doi.org/10.1037/0021-9010.91.1.126

Kang, H. J., Gatling, A., \& Kim, J. (2015). The impact of supervisory support on organizational commitment, career satisfaction, and turnover intention for hospitality frontline employees. Journal of Human Resources in Hospitality \& Tourism, 14(1), 68-89. https://doi.org/10.1080/15332845.2014.904176

Khalfa, S. D., Roy, M., Peretz, I., \& Lupien, S. J. (2003). Effects of relaxing music on salivary cortisol level after psychological stress. Annals of the New York Academy of Sciences, 999(1), 374-376. https://doi.org/10.1196/annals.1284.045

Knight, W. E., \& Rickard, N. S. (2001). Relaxing music prevents stress-induced increases in subjective anxiety, systolic blood pressure, and heart rate in healthy males and females. Journal of Music Therapy, 38(4), 254 272. https://doi.org/10.1093/jmt/38.4.254

Kumudha, A., \& Abraham, S. (2008). Organization career management and its impact on career satisfaction: A study in the banking sector. ICFAI University Journal of Bank Management, 7(3), 71-84. Retrieved from https://ideas.repec.org/a/icf/icfjbm/v7y2008i3p48-58.html

Kyriacou, C. (2001). Teacher stress: Directions for future research. Educational Review, 53(1), 27-35. https://doi.org/10.1080/00131910120033628

Larchick, R., \& Chance, E. (2004). Teacher performance and personal life stressors: Implications for urban life school administrators. National Forum of Teacher Education Journal, 14E, 19-30.

Lepnurm, R., Dobson, R., Backman, A., \& Keegan, D. (2007). Factors associated with career satisfaction among general practitioners in Canada. Canadian Journal of Rural Medicine, 12(4), 217-230. Retrieved from https://www.ncbi.nlm.nih.gov/pubmed/18076815

Maddock, C., \& Pariante, C. M. (2001). How does stress affect you? An overview of stress, immunity, depression and disease. Epidemiology and Psychiatric Sciences, 10(3), $153-162$. https://doi.org/10.1017/S1121189X00005285

Magee, W. L., \& Davidson, J. W. (2002). The effect of music therapy on mood states in neurological patients: A pilot study. Journal of Music Therapy, 39(1), 20-29. https://doi.org/10.1093/jmt/39.1.20

Martins, L. L., Eddleston, K. A., \& Veiga, J. F. (2002). Moderators of the relationship between work-family conflict and career satisfaction. Academy of Management Journal, 45(2), 399-409. https://doi.org/10.5465/3069354

McEwen, B. S. (2009). Stress: Homeostasis, rheostasis, allostasis and allostatic road. In G. Fink (Ed.), Stress 
science: Neuroendocrinology (1st ed., pp. 3-9). San Diego, CA, USA: Academic Press. https://doi.org/10.1016/B978-008045046-9.00077-2

Montgomery, C., \& Rupp, A. A. (2005). A meta-analysis for exploring the diverse causes and effects of stress in teachers. Canadian Journal of Education/Revue Canadienne de L'éducation, 28(3), 458-486. https://doi.org/10.2307/4126479

National Institute of Mental Health. (2018, February). Depression. Retrieved June 7, 2019, from https://www.nimh.nih.gov/health/topics/depression/index.shtml

Olinger, L. J., Kuiper, N. A., \& Shaw, B. F. (1987). Dysfunctional attitudes and stressful life events: An interactive model of depression. Cognitive Therapy and Research, 11(1), 25-40. https://doi.org/10.1007/BF01183130

Parayitam, S., Desai, K. J., Desai, M. S., \& Eason, M. K. (2010). Computer attitude as a moderator in the relationship between computer anxiety, satisfaction, and stress. Computers in Human Behavior, 26(3), 345352. https://doi.org/10.1016/j.chb.2009.11.005

Parekh, R. (2017, January). What is depression? Retrieved June 7, 2019, from https://www.psychiatry.org/patients-families/depression/what-is-depression

Payne, B. K., Blackwell, B. S., \& Collins, S. C. (2010). Education and career satisfaction: Examining the specifics of the relationship among criminal justice graduates. Journal of Police and Criminal Psychology, 25(2), 105-112. https://doi.org/10.1007/s11896-009-9058-7

Riaz, A., \& Haider, M. H. (2010). Role of transformational and transactional leadership on job satisfaction and career satisfaction. Business and Economic Horizons, 1(1), 29-38. Retrieved from https://www.ceeol.com/search/article-detail?id $=60124$

Ripski, M. B., LoCasale-Crouch, J., \& Decker, L. (2011). Pre-service teachers: Dispositional traits, emotional states, and quality of teacher-student interactions. Teacher Education Quarterly, 38(2), 77-96. Retrieved from https://www.jstor.org/stable/23479694

Scheib, J. W. (2003). Role stress in the professional life of the school music teacher: A collective case study. Journal of Research in Music Education, 51(2), 124-136. https://doi.org/10.2307/3345846

Selye, H. (1976). Stress in health and disease. Stoneham, MA, USA: Butterworth-Heinemann.

Sherina, M. S., Rampal, L., \& Kaneson, N. (2004). Psychological stress among undergraduate medical students. Medical Journal of Malaysia, 59(2), 207-211.

Shin, H., Noh, H., Jang, Y., Park, Y. M., \& Lee, S. M. (2013). A longitudinal examination of the relationship between teacher burnout and depression. Journal of Employment Counseling, 50(3), 124-137. https://doi.org/10.1002/j.2161-1920.2013.00031.x

Siedliecki, S. L., \& Good, M. (2006). Effect of music on power, pain, depression and disability. Journal of Advanced Nursing, 54(5), 553-562. https://doi.org/10.1111/j.1365-2648.2006.03860.x

Siegrist, J. (2008). Chronic psychosocial stress at work and risk of depression: evidence from prospective studies. European Archives of Psychiatry and Clinical Neuroscience, 258(5), 115. https://doi.org/10.1007/s00406-008-5024-0

Smith, A., Brice, C., Collins, A., Matthews, V., \& McNamara, R. (2000). The scale of occupational stress: A further analysis of the impact of demographic factors and type of job. London, UK: HSE.

Spahn, C., Strukely, S., \& Lehmann, A. (2004). Health conditions, attitudes toward study, and attitudes toward health at the beginning of university study: Music students in comparison with other student populations. Medical Problems of Performing Artists, 19(1), 26-34.

Steptoe, A. (1989). Stress, Coping and Stage Fright in Professional Musicians. Psychology of Music, 17(1), 3-11. https://doi.org/10.1177/0305735689171001

Sternbach, D. J. (2008). Stress in the lives of music students. Music Educators Journal, 94(3), 42-48. https://doi.org/10.1177/002743210809400309

Tsai, E., Fung, L., \& Chow, L. (2006). Sources and manifestations of stress in female kindergarten teachers. International Education Journal, 7(3), 364-370. Retrieved from https://eric.ed.gov/?id=EJ847318

Tschannen-Moran, M., Hoy, A. W., \& Hoy, W. K. (1998). Teacher efficacy: Its meaning and measure. Review of Educational Research, 68(2), 202-248. https://doi.org/10.3102/00346543068002202 
Uzman, E., \& Telef, B. B. (2015). Öğretmen adaylarının ruh sağlığı ve yardım arama davranışları. Düşünen Adam: Psikiyatri ve Nörolojik Bilimler Dergisi, 28, 242-254. https://doi.org/10.5350/DAJPN2015280307

Vaag, J., Bjørngaard, J. H., \& Bjerkeset, O. (2016). Symptoms of anxiety and depression among Norwegian musicians compared to the general workforce. Psychology of Music, 44(2), 234-248. https://doi.org/10.1177/0305735614564910

Waldon, E. G. (2001). The effects of group music therapy on mood states and cohesiveness in adult oncology patients. Journal of Music Therapy, 38(3), 212-238. https://doi.org/10.1093/jmt/38.3.212

Welch, J. L., \& Austin, J. K. (2001). Stressors, coping and depression in haemodialysis patients. Journal of Advanced Nursing, 33(2), 200-207. https://doi.org/10.1111/j.1365-2648.2001.01654.x

Whisman, M. A., \& Richardson, E. D. (2015). Normative data on the Beck Depression Inventory-second edition (BDI - II) in college students. Journal of Clinical Psychology, 71(9), 898-907. https://doi.org/10.1002/jclp.22188

Wills, G. I., \& Cooper, C. L. (1987). Stress and professional popular musicians. Stress Medicine, 3(4), 267-275. https://doi.org/10.1002/smi.2460030407

Wong, C. A., \& Laschinger, H. K. (2013). Authentic leadership, performance, and job satisfaction: The mediating role of empowerment. Journal of Advanced Nursing, 69(4), 947-959. https://doi.org/10.1111/j.1365-2648.2012.06089.x

Wristen, B. G. (2013). Depression and anxiety in university music students. Update: Applications of Research in Music Education, 31(2), 20-27. https://doi.org/10.1177/8755123312473613

Yerlikaya, E. E., \& İnanç, B. (2007). Algılanan stres ölçeğinin Türkçe çevirisinin psikometrik özellikleri. Paper presented at IX. Ulusal Psikolojik Danışma ve Rehberlik Kongresi, İzmir, Turkey.

Zembylas, M., \& Papanastasiou, E. (2004). Job satisfaction among school teachers in Cyprus. Journal of Educational Administration, 42(3), 357-374. https://doi.org/10.1108/09578230410534676

Zhao, H., \& Zhang, X. (2017). The influence of field teaching practice on pre-service teachers' professional identity: A mixed methods study. Frontiers in Psychology, 8(1264), 1-11. https://doi.org/10.3389/fpsyg.2017.01264

\section{Copyrights}

Copyright for this article is retained by the author, with first publication rights granted to the journal.

This is an open-access article distributed under the terms and conditions of the Creative Commons Attribution license (http://creativecommons.org/licenses/by/4.0/). 